making his study more than just a paean to a vintage piece of frontier-busting.

One wonders whether anything worthwhile remains to be said about the Alaska Highway (as distinct from a series of parochial discussions of its impact on individual communities). If any aspect has been under-studied, it is the Alaskan portion. This reviewer has made a modest contribution by addressing (in a study of Alaskan engineering projects) the role of frontier images during promotion and construction, the environmental impact, and those who felt that the drawbacks of an overland link with the rest of the USA outweighed the benefits. Yet we still don't know enough about its impact on Alaskan natives.

North to Alaska! is aimed at increasing number of Southlanders who take the road to Alaska in response to the call of the wild. Author and publisher no doubt hope this book will grace motel lobby coffee tables and gift shop shelves as often as libraries. For those vicarious, summer pionecrs searching for the last frontier in their motor homes and luxury coaches, it will prove the most useful and durable of souvenirs. (Peter A. Coates, Department of Historical Studies, University of Bristol, 13-15 Woodland Road, Bristol BS8 1TB.)

OTTER SKINS, BOSTON SHIPS AND CHINA GOODS: THE MARITIME FUR TRADE OF THE NORTHWEST COAST, 1785-1841. James R. Gibson. 1992. Montreal, Kingston, and London, McGill-Queen's University Press. 422 p, illustrated, hard cover. ISBN 07735-0829-5. £29.95.

The sca-otter or maritime fur trade was an international economy that developed in consequence of Captain James Cook's third voyage of exploration to the Pacific and his visit to Nootka Sound and the Gulf of Alaska in 1778. For the previous half century, the Russians had kcpt the secrets of the trade from the wider world. By the last decade of the eighteenth century Boston traders had come to dominate a trade that had been, for a short time, British led. Until the 1840 s an ever dwindling trade in sea-otter pelts connected the northwest coast of North America to the ports of London, Boston, and Montreal. The depletion of these sea mammals ended the trade, whose major market, unlike the beaver, was in Canton and Macao, where Chinese mandarins used sea-otter pelts for decorating clothing. For a brief period of time, therefore, 'the ermine of Asia,' as the sea otter was known, played a substantial rolc in Pacific Ocean history and in the interrelationship of Russian, Boston, and British traders, northwest coast native peoples, and Chinese consumers and traders.

Gibson's study is international in its scope, and it begins with an assessment of northwest coast native practices and trade. The pre-contact internecine trade was changed by the coming of Cook and other European traders, and it went through several changes as Russian, British, and American shipscame to the northwest to trade. The author describes the fluctuations of the trade, and explains how ascendancy passed from trader to trader and even from nation to nation. Using the very large corpus of ships logs, hitherto unused in such a systematic way, he has reconstructed the main features of the trade, from the offshore islands of British Columbia and Alaska to the Pacific Islands, where ship crews would rest and replenish supplies, to Canton and Macao where sea-otter pelts would be exchanged for porcelain, tea, silk, and other commodities, and to Boston and London, where oriental produce would be offloaded and hardware and other merchandise loaded for the Pacific Northwest. The author documents the several phases of this trade, and he explains how smaller, more economically operated American vessels had a distinct advantage in out-trading rivals from other countries. Moreover, he demonstrates that British traders were frequently hindered by circumstances of war (1792-1815) and by chartered corporate restrictions possessed by the East India Company. Hitherto unexploited Russian sources add a valuable dimension to the story.

Of his numerous tables and appendices, that entitled 'Trading and hunting vessels on the Northwest Coast, 1785-1841' may be singled out in value. It lists by nationality and year each and every vessel engaged in the trade; it is based on a wide array of cited sources. Other tables recount the value of American exports to the northwest coast, the value of American fur sales at Canton, Hudson's Bay Company ships in the coast trade, British and American sea and land fur returns, number of foreign shipsat Canton during 1787-1833, furs imported by Amcrican vessels at Canton, prices of sea otters in Canton, and commodity composition by value of Amcrican imports at Canton. This book is richly illustrated, fulsomely footnoted, and has an excellent bibliography and index. It is only to be regretted that there is no ships' names index.

Many years ago Judge F.W. Howay began the laborious rescarch of describing and analysing the maritime fur trade. While Howay's research will always be central to our understanding of this branch of commerce, it is important to note that Gibson has provided the first scholarly assessment of an international economy. He does not strain for any final thematic explanation, but his treatment of subthemes, such as muskets serving as trade items for Pacific Northwest natives, adds significantly to the discussion of this contentious subject and enriches our understanding of natives aspect of the trade. This is an important and original book and a valuable contribution to our understanding of the history of the sea-otter trade and of the human activities that ensued as merchant mariners sought to carry pelts from Nootka to Canton, and in the process brought the wider world into an interrelated trading network. (Barry Gough, History Department, Wilfrid Laurier University, Waterloo, Ontario N2L 3C5, Canada.)

THE AURORA WATCHER'S HANDBOOK. Neil Davis. 1992. Fairbanks, University of Alaska Press. 230 p, illustrated, soft cover. ISBN 0-912006-60-9. \$20.00 (US).

The aurora (northern or southern lights) is one of the most spectacular and awe-inspiring of the many optical phe- 
nomena that can occur in the earth's atmosphere. It is mainly a phenomenon of the Arctic and Antarctic regions, the zones of maximum occurrence being roughly between 1300 and $3000 \mathrm{~km}$ of the earth's geomagnetic poles (located approx imately at Thule in Greenland and at Vostok in Antarctica). No-one who has ever seen its display of dancing green and red light against the night sky can have failed to want to know at least a little more about it. Not surprisingly, it has generated many myths and legends among those who live in the northern lands from which it is frequently visible. According to a tradition of the Russian Lapps, the aurora is blood spilt on the floor of the house of the dead as the spirits of murdered men engage in mighty battles. Whistling at it (or ringing sleigh-bells) is dangerous; it may attract the aurora's attention, bringing it sufficiently close to tear out one's eyes, so it is therefore perhaps useful to recall that, according to a similar North American tradition, an aurora can be scared away by flinging a frozen dog turd at it. Modem myths also abound. Erroneous but purportedly scientific explanations are still sometimes given in terms of sunlight reflected from icebergs, airborne ice crystals, and so on. In fact, the aurora is caused when oxygen atoms very high (typically $100 \mathrm{~km}$ ) in the earth's atmosphere are stimulated to produce light when they are bombarded with high-specd electrons emitted by the sun. The process is a complicated one, and its study reveals a great deal about the complexities of some of the interactions between the sun and the earth.

Neil Davis' book claims the status of a handbook, which implies, for me, that it should contain, in a readily accessible form, as much information as anyone could reasonably want about the aurora. The author, a distinguished geophysicist from the University of Alaska who has spent most of his scientific career studying it, achicves this end very effectively by dividing the book into two parts. The first part (about a third of the book) provides a very clear description and explanation of auroral phenomena aimed at the lay reader, and suggestions on the best way to observe and photograph them. The first chapter gives an explanation of the aurora suitable for a child, say, 10 years old. This, I think, works brilliantly well, and I strongly suspect that it is based on personal experience. Of the remaining two thirds of the book, helpfully headed 'For those who want to learn more,' the first half builds up a fairly detailed technical explanation of the phenomena, including a discussion of some of the latest research, which could easily serve as an introduction to the subject for a rescarch student. The chapters discussing the operation of the magnetohydrodynamic dynamo driven by the solar wind as it interacts with the earth's magnetosphere are necessarily complicated, and the reader who is not a physics graduate might have to take some of the statements here on trust, but, overall, the discussion is convincing and very well informed. The last third of the book describes much of the folklore relating to auroral phenomena, and treats, at a reasonably non-technical level, unknown aspects of auroral processes, the possible interactions be- tween the aurora and weather, and the unproved phenomenon of auroral sound.

Davis' book is clearly written, and well-illustrated with diagrams (some technical, and some quirky but rather amusing cartoons), black-and-white photographs that are occasionally somewhat lacking in contrast, and 27 superb colour plates. There is a good index, a helpful glossary of technical terms, and a short but up-to-date list of suggestions for further reading. In short, the author has succeeded in producing a concise work that will appeal to readers at many levels, and that contains an impressively large amount of accessible information. My only real criticism relates to the physical quality of the paperback edition, whose covers tend to curl up. (Gareth Rees, Scott Polar Research Institute, Lensfield Road, Cambridge CB2 1ER.)

\section{INUJJUAMUIT FORAGING STRATEGIES: EVO- LUTIONARY ECOLOGY OF AN ARCTIC HUNT- ING ECONOMY. E.A. Smith. 1992. New York, Aldine de Gruyter. 455 p, soft cover. ISBN 3-11-013269-9.}

This book is a substantial study of the Inuit hunting economy in Inujjuaq, Qucbec. Based on ficldwork during the late 1970s, it analyses in fine and heady detail the material investments and material outcomes of some 600 hunting and gathering - or what the author calls foraging -trips, drawing on data from both direct participation and interviews.

Arguing that "it is still logically valid and analytically uscful to separate the personal experience and reactions of the ethnographer from the data she or he collects during fieldwork' (page 144), Eric Alden Smith has not allowed a post-modernist, humanist, or literary style to get in the way of straight-forward empirical inquiry. Rather,Smith's main theoretical concern is with the application of evolutionary ecology to the study of human foraging strategies. Following a summary of the tenets of evolutionary ecology and a defence of optimal foraging theory, Smith places the Inujjuamiut economy within its natural and human historical scutings before launching into a lengthy discussion of contemporary foraging patterns, prey choice, time allocation and patch choice, cooperative foraging, and foraging within the context of a mixed cconomy.

The underlying framework is neo-Darwinian, with Smith taking the position that "natural selection is a powerful (but not omnipotent) explanatory framework for understanding ecological and behavioural variation in our species' (page 31). In defending his approach the author discusses and evaluates the major criticisms of a Darwinian approach to optimal foraging and oulines its methodology, structure, and logic. There is much in this book about models of foraging efficiency, time/energy costs, inclusive energy expenditure, quantitative analysis of prey choice, net capture rates, and monthly time allocation and retum. Smith suggests that, as 'one of very few extensive quantitative tests of foraging theory with human foragers' (page 406), the book has relevance and significance for rescarch on hunter-gatherer peoples outside of the 